\title{
Changes on Sugar and Starch Contents during Seed Development of Synergistic Sweet Corn and Implication on Seed Quality
}

\author{
Bhornchai Harakotr (D), Warisa Sutthiluk, and Panumart Rithichai \\ Department of Agricultural Technology, Faculty of Science and Technology, Thammasat University, Bangkok, \\ Pathum Thani 12120, Thailand \\ Correspondence should be addressed to Bhornchai Harakotr; harakotr@tu.ac.th
}

Received 22 October 2021; Revised 10 February 2022; Accepted 11 February 2022; Published 7 March 2022

Academic Editor: Othmane Merah

Copyright (c) 2022 Bhornchai Harakotr et al. This is an open access article distributed under the Creative Commons Attribution License, which permits unrestricted use, distribution, and reproduction in any medium, provided the original work is properly cited.

\begin{abstract}
Synergistic sweet corn equipped with multiple-recessive genes encoding sugar synthesis is proposed through hybrid breeding to improve the balance eating quality including flavor, texture, and aroma. However, the drawback on seed quality occurs such as low germination and poor seedling vigor. This study aimed to investigate the changes of carbohydrate contents on seed quality of five sweet corn genotypes differing in the number of equipped recessive genes during seed development. Seeds were sampled at 4-day intervals from 18 to 46 days after pollination (DAP) and analyzed for seed germination, sugar, water-soluble polysaccharide, and starch. Then, their relationships were analyzed by using time series regression analysis. Although there were significant differences among 5 corn genotypes in their seed germination and carbohydrate contents, some genotypes showed responses in similar patterns. The optimal time to harvest seeds was genotype-dependent, which were 38 DAP for triple-recessive gene (btbtsh $\left.h_{2} h_{2} w x w x\right)$ and single-recessive genes $\left(B t B t s h_{2} s h_{2} W x W x\right.$ and $\left.S h_{2} S h_{2} s u s u W x W x\right)$ and 42 DAP for double-recessive genes $\left(B t B t s h_{2} s h_{2} w x w x\right)$. The regression analysis revealed that seed germinability could be predicted by total starch content in synergistic sweet corn lines during seed development stages; however, this prediction seemed to be negligible in sweet corn genotypes equipped with a single-recessive gene. Implications and further suggestions for establishing an effective seed production technique and seed quality of synergistic sweet corn are discussed.
\end{abstract}

\section{Introduction}

Sweet corn (Zea mays L. saccharata) is a vegetable crop widely cultivated and consumed all over the world as it possesses good flavor, tenderness, and aroma that appeal to consumer preferences [1]. This crop is also rich in nutritional values, minerals, and antioxidants, benefiting human health $[2,3]$. Nowadays, the volume of Thai sweet corn export is expanding due to competition on the price and quality of sweet corn. In 2019, the total harvest area of Thai sweet corn occupies more than 80,198 hectares, yielding 501,242 tons [4]. However, the sweet corn producers and industries require more reliable cultivars that could be accomplished by hybrid breeding with high seed qualities [2].
Sweet corn can be classified into five types based on the gene compositions in the endosperm: normal (sugary gene, $s u_{1}$ ), sugary enhanced (sugary enhanced gene, se), super sweet (shrunken gene, $s h_{2}$, or brittle gene, $b t_{1}$ ), synergistic, and augmented shrunken genotypes [5]. Synergistic corn equipped with $s u_{1}, s h_{2}$, and $s e$ combinations gives a balance eating quality between high sugar content and tenderness $[6,7]$. Moreover, these recessive genes encoding sweetness have been utilized to improve the eating quality of traditional waxy corn through sweet-waxy corn hybrids [7-10]. However, the adverse effects on seed qualities were found in sweet corn genotypes with two or more recessive genes controlling sugar synthesis. Pairochteerakul et al. [11] reported that incorporations of either $b t_{2}$ or $s h_{2}$ gene into $w x$ background resulted in low germination percentage and 
TABLE 1: Five sweet corn genotypes used in this study.

\begin{tabular}{lccc}
\hline Inbreds/hybrid & Types & Genotypes & Phenotypes \\
\hline 101LTSC-10 & Inbred lines; triple-recessive genes & $b t b t s h_{2} s h_{2} w x w x$ & Super sweet corn \\
C4 & Inbred lines; double-recessive genes & $B t B t s h_{2} s h_{2} w x w x$ & Super sweet corn \\
TSC/H3-7 & Inbred lines; single-recessive gene & $B t B t s h_{2} s h_{2} W x W x$ & Super sweet corn \\
P4546/Delec-1 & Inbred lines; single-recessive gene & $S_{2} \operatorname{Sh}_{2} s u s u W x W x$ & Sweet corn \\
Dr. Pek's 1351 & Hybrid; single-recessive gene & $B t B t s h_{2} s h_{2} W x W x$ & Super sweet corn \\
\hline
\end{tabular}

poor seedling vigor. This situation would be unfavorable for hybrid seed production. Several approaches have been proposed to address that issue by using either conventional or molecular breeding, seed production techniques, and seed enhancement technologies [12-14].

Seed vigor is essential to enhance a rapid, uniform seed emergence under various field conditions and to extend seed storability; thus, this parameter is commonly included in routine seed testing $[13,15]$. Vigorous hybrid seeds demonstrating rapid germination, high germination percentage, and uniform seedling growth are associated with high potential yield in crop production $[15,16]$. Being one of the complex agronomic traits, seed vigor is a manifestation of genetics, environmental conditions during seed development, dates of harvest, mechanical handlings, dryings, storage conditions, storage periods, and storage insect pests [17-19]. In this context, the seed developmental stage is critical affecting seed vigor and correlated with the timing of harvest or seed maturation stage [17]. In sweet corn genotypes, alterations of seed germination and vigor during seed development and maturation correspond to any changes in seed morpho-physiological traits [20-22]. Seed storage reserves including sugar and starch are another key factor influencing seed vigor because these carbohydrates are converted to soluble sugars as energy for initial seed germination and seedling growth [23]. During seed development, the concentrations of hexose sugars (glucose, fructose, glucose 6-phosphatase, and fructose 6-phosphatase) are progressively declining whereas storage carbohydrates such as sucrose, starch, and raffinose family oligosaccharides (mainly raffinose, stachyose, and verbascose) are increasing [24]. A previous study noticed that kernel carbohydrate profiles of sweet corn genotypes at the maturity stage had an impact on seed quality [11, 25]; however, such investigation at each seed development of synergistic sweet corn genotypes has not been reported. Here, we analyzed the relationship between carbohydrate characters and seed germination across the seed developmental stages of synergistic sweet corn genotypes differing in the number of equipped recessive genes by using the time series regression technique. Our findings suggested that carbohydrate characters should be considered to optimize the seed qualities of synergistic sweet corn in the seed production technology.

\section{Materials and Methods}

2.1. Seed Materials and Field Experiment. Four sweet corn inbred lines ( $\mathrm{F}_{7}$ generation) and one sweet corn $\mathrm{F}_{1}$ hybrid differing in genes controlling endosperm carbohydrate characters were used in this study (Table 1). Inbred line 101TSC-10 has triple-recessive genes (btbtsh $\left.{ }_{2} s h_{2} w x w x\right)$ whereas $\mathrm{C} 4$ has double-recessive genes (BtBtsh $\left.h_{2} s h_{2} w x w x\right)$. Both lines are synergistic sweet corn, screened by both visual selection and microsatellite markers during 2014-2017 [11]. Inbred lines TSC/H3-7 and P4546/Delec-1 have single-recessive allele $s h_{2}\left(B t B t s h_{2} s h_{2} W x W x\right)$ and $s u$ $\left(\mathrm{Sh}_{2} \mathrm{Sh}_{2}\right.$ susuWxWx), respectively. Dr. Pek's 1351 is a popular super sweet corn hybrid $\left(B t B t s h_{2} s h_{2} W x W x\right)$ variety from Sweet Seeds Co. Ltd.

Each genotype was planted at the Department of Agricultural Technology, Thammasat University, Pathum Thani, Thailand, in the dry season of 2019/2020 (November 2019-February 2020). This site had loamy sand soils with a $\mathrm{pH}$ of 4.84 , an electrical conductivity of $0.94 \mathrm{dS} \cdot \mathrm{m}^{-1}$, and $0.31 \mathrm{mg} \cdot \mathrm{kg}^{-1} \mathrm{~N}, \quad 110.95 \mathrm{mg} \cdot \mathrm{kg}^{-1} \mathrm{P}$, and $34.00 \mathrm{mg} \cdot \mathrm{kg}^{-1} \mathrm{~K}$. Each genotype was grown in 10 rows and $5 \mathrm{~m}$ in length, with a spacing of $0.75 \mathrm{~m}$ between rows. The distance between hills in a row was $0.25 \mathrm{~m}$; hence, the population density was 5.33 plants $\mathrm{m}^{-2}$. The Department of Agriculture, Thailand, recommendations [26] were followed for field management. Before planting, fertilizer formula 15-15-15 of NPK was applied at a rate of $312.5 \mathrm{~kg} \cdot \mathrm{ha}^{-1}$, and $156.25 \mathrm{~kg} \cdot \mathrm{ha}^{-1}$ of fertilizer formula $46-0-0$ was applied at 20 and 40 days after planting. Weed control was accomplished by hand weeding at critical periods of crop whereas pesticides were applied when the crop reached the economic injury level. Hand-pollination was performed on each genotype to avoid unintended pollen contamination.

2.2. Seed Harvest. Sweet corn seed is ready to harvest at about 30-40 days after pollination (DAP), but the seed starts acquiring germinability at 14 DAP [15]. Twenty hand-pollinated ears of each genotype were sampled randomly at the 4-day intervals from 18 to 46 DAP to monitor the seed development at different stages. Immediately after sampling at each harvest interval, 200 seeds of the middle ear part were shelled by hand for dual purposes. For the first purpose, 100 seeds were frozen in liquid nitrogen to stop all metabolic activities. Then, samples were dried with lyophilization and stored at $-20^{\circ} \mathrm{C}$ for subsequent chemical analyses. For the second purpose, 100 seeds were used to determine seed moisture content and 100-seed dry weight. The remaining corn seeds within the ear were dried at $35^{\circ} \mathrm{C}$ until constant moisture content, and the seeds were then threshed from the cob. The dried seeds were stored in sealed containers at $15^{\circ} \mathrm{C}$ and $50 \%$ humidity for further seed quality tests. 
2.3. Seed Moisture Content and 100-Seed Dry Weight. Seed moisture content was determined using International Seed Testing Association (ISTA) method [27]. One hundred kernels per sample were dried for $24 \mathrm{~h}$ in a drying oven with a temperature set at $103^{\circ} \mathrm{C}$. The samples were kept in a desiccator to cool down for 30-45 min, and then the weights were recorded as seed dry weight. Seed moisture was calculated as follows:

$$
f=\left[\frac{\left(M_{2}-M_{3}\right)}{\left(M_{2}-M_{1}\right)}\right] \times 100,
$$

where $f$ is the kernel moisture content (\%); $M_{1}$ is the weight ( $g$ ) of the used container and its cover; $M_{2}$ is the weight ( $\mathrm{g}$ ) of the container, its cover, and the kernels before drying in the oven; and $M_{3}$ is the weight (g) of the container, its cover, and the seeds after drying in the oven. Each genotype sample was measured with four replicates.

2.4. Seed Quality Tests. Standard germination tests [27] were performed using four replicates per sample with 50 seeds per replicate. Seeds of each sample were placed in germination boxes $(12 \times 18 \times 9 \mathrm{~cm})$. For the growing media, peat moss was added and moistened with water to $9 \%(w / w)[22,23]$. The boxes were stored in a room under constant temperature at $25^{\circ} \mathrm{C}$ for 7 days. Germinated seeds were counted daily. After 7 days, the germination percentage was calculated as the percentage of normal germinated seeds to all tested seeds at the end of the full tests [28].

Based on the number of germinated seeds after 7 days, the germination index was calculated as follows:

$$
\mathrm{GI}=\frac{\sum G_{t}}{T_{t}},
$$

where $G_{\mathrm{t}}$ is the germinated seeds on day $t$ and $T_{\mathrm{t}}$ is the time corresponding to $G_{t}$ in days. Mean germination time was calculated as follows:

$$
\operatorname{MGT}=\frac{\sum T_{i} N_{i}}{\sum N_{i}},
$$

where $N_{\mathrm{i}}$ is the number of germinated seeds on day $i$ and $T_{\mathrm{i}}$ is the time after sowing.

An electrical conductivity test was carried out with four replicates. Each replicate derived from 25 seeds was sampled for $0.01 \mathrm{~g}$ and was soaked in a beaker $(200 \mathrm{~mL})$ containing $150 \mathrm{~mL}$ distilled water at $20^{\circ} \mathrm{C}$ for $24 \mathrm{~h}$ [27]. After soaking, the $\mathrm{EC}$ value was determined using a conductivity meter (ver. HI98311, Hanna instruments, RI, USA) with an electrode with constant 1.

2.5. Seed Carbohydrate Composition Analyses. Soluble sugar contents were extracted and determined by using the phenolic-sulfuric acid method [25]. Briefly, the samples were ground with blender, then ground samples were sieved through a $63 \mu \mathrm{m}$ sieve. Fifty milligrams of samples were extracted with $3 \mathrm{~mL}$ of $80 \%$ aqueous ethanol in a glass tube, and the extract was heated at $65^{\circ} \mathrm{C}$ for $1 \mathrm{~h}$ to obtain the soluble sugar. The supernatants were then moved to new glass tubes containing ethanol, and the residual was further extracted twice. The final extracts derived from ethanol solutions were adjusted to $9 \mathrm{~mL}$ and filtered through a $0.45 \mu \mathrm{m}$ filter (Millipore Corp., MA, USA) for sugar quantification. Reversed-phase HPLC analysis of mono- and disaccharide was performed using a Shimadzu system (Shimadzu, Japan) equipped with a binary pump (LC-20AC pump) and a refractive index detector (RID-10A). Chromatographic separations were performed on a Sugar-Pak I column $(6.5 \times 300 \mathrm{~mm}$, i.d. $10 \mu \mathrm{m})$ (Waters, MA, USA). The mobile phase was deionized water at the flow rate of $0.5 \mathrm{ml} /$ min. Column operating conditions were as follows: temperature $80^{\circ} \mathrm{C}$ and injection volume of $10 \mu \mathrm{l}$. Different dilutions of individual external standards ranging from low to high concentrations were made, and standard curves were plotted. The results of individual sugar contents were expressed as milligram per gram of dry weight $\left(\mathrm{mg} \mathrm{g}^{-1}\right.$ dry weight). Total sugar content was calculated from the sum of each sugar fraction content.

Three parameters including phytoglycogen, amylopectin, and total starch contents were also determined by using the phenolic-sulfuric acid method [25]. Each dried sample was isolated from the native starches with four replications. To inactivate the enzymes, $100 \mathrm{~g}$ of each sample was soaked in $0.16 \%$ sodium hydrogen sulfite at $50^{\circ} \mathrm{C}$ for $24 \mathrm{~h}$. Immediately after soaking, the sample was ground in the blender and then sieved through a $105 \mu \mathrm{m}$ sieve-mesh. The slurry ground samples were put in toluene alcohol for native starch separation and were dried at $80^{\circ} \mathrm{C}$ for $24 \mathrm{~h}$. For starch extraction, $50 \mathrm{mg}$ of native starch powder was extracted with $80 \%$ ethanol and then heated at $80^{\circ} \mathrm{C}$ for $1 \mathrm{~h}$. Phytoglycogen and total starch contents were measured at the wavelength of 490 and $600 \mathrm{~nm}$, respectively (Shimadzu mod. UV-128, Japan). The results of phytoglycogen and total starch contents were expressed as milligram per gram of dry weight ( $\mathrm{mg} \mathrm{g}^{-1}$ dry weight).

Amylopectin content was measured according to Simla et al. [25]. Twenty grams each of a series of pure amylose and amylopectin (ranging from 0 to $100 \%$ amylopectin) were dissolved in $10 \mathrm{~mL}$ of $90 \%$ dimethyl sulfoxide. Then, $1 \mathrm{~mL}$ of the diluted solution was mixed with $1 \mathrm{~mL}$ iodine solution and adjusted to $10 \mathrm{~mL}$ with distilled water. The solution was stood for $15 \mathrm{~min}$ for color establishment. The absorbance of the standard mixture at $600 \mathrm{~nm}$ was measured (Shimadzu mod. UV-128, Japan). The result of total amylopectin content was expressed as milligram per gram of dry weight (mg $\mathrm{g}^{-1}$ of dry weight).

2.6. Statistical Analysis. Analysis of variance (ANOVA) was subjected to all parameters. The least significant difference (LSD) was used for mean comparison at 0.01 probability level [29]. These analyses were done using the Statistix program (ver. 10.0, Analytical Software, FL, USA). Regression equations between seed carbohydrate profiles and seed germination were conducted by using SPSS software (ver. 26, IBM Crop., NY, USA). The graphs were then plotted by Microsoft excel (ver. 2016, Microsoft, WA, USA). 


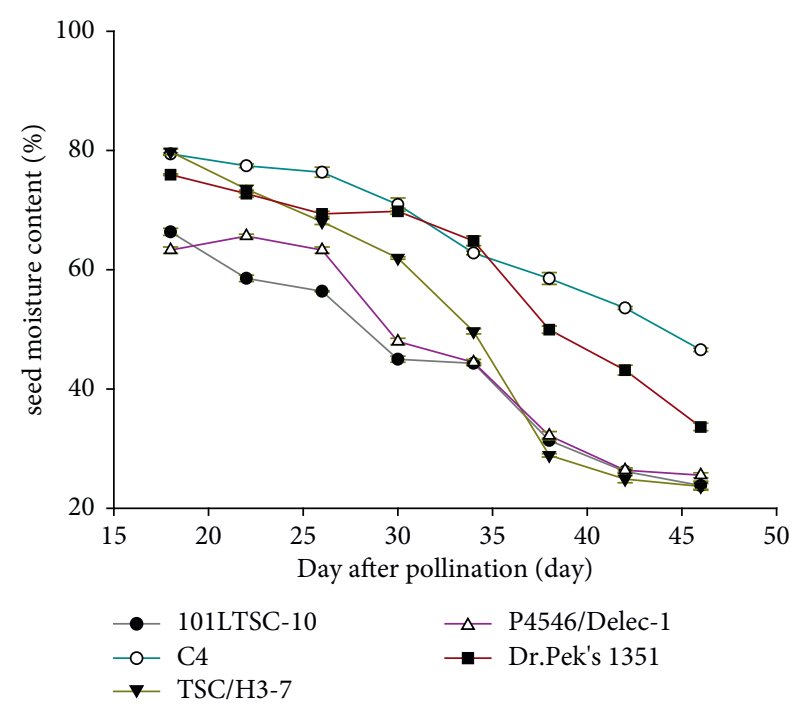

(a)

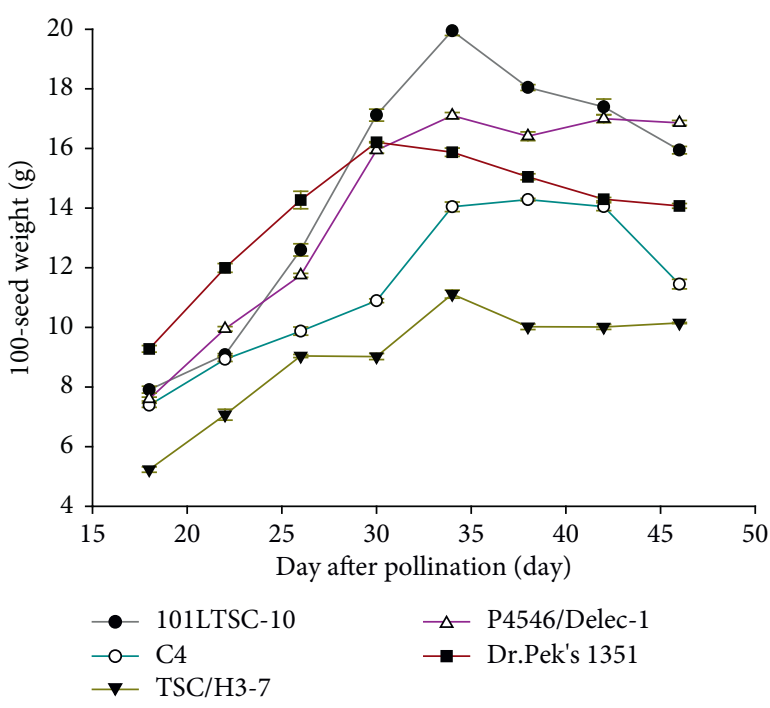

(b)

FIGURE 1: The changes of seed physical parameters during seed developments of sweet corn: (a) seed moisture content and (b) 100-seed dry weight. The data are means of four replicate samples and error bar $\pm \mathrm{SD}(n=4)$.

\section{Results and Discussion}

Normally, seed development can be distinguished into three stages as follows: stage I, rapid cell division; stage II, rapid synthesizing of storage materials; and stage III, the little synthesis of storage material and dehydration [30]. The terminal stage of seed development called the maturation stage occurred between 30 and 40 days after anthesis in sweet and waxy corn $[12,21,23]$. However, seeds gain the ability to germinate at 14 and 21 DAP for sweet and waxy corns, respectively $[12,22]$. Our preliminary study found that all tested genotypes were not germinated at 14 DAP. Previous studies reported the low germination rates of sweet corn genotypes harvested at between 11 and 15 DAP because of inadequate seed endosperm $[21,31]$. Therefore, the changes of seed germination and carbohydrate contents of single-, double-, and triple-recessive sweet corn genotypes from 18 to 46 DAP were evaluated in this study.

3.1. Changes in Seed Moisture Content and Seed Dry Weight during Seed Development. Physiological maturity greatly influenced by genetic and environmental factors has been recognized to determine the proper timing of harvest in seed production. Several criteria are commonly used to indicate physiological maturity in sweet corn including black layer formation, seed dry matter, seed moisture content, and milk line development [32, 33]. Among these parameters, kernel moisture content and seed dry weight accumulation after pollination are the simple methods to apply [32]. In general, the seed moisture content of all sweet corn genotypes was decreasing gradually along with their seed developments (Figure 1(a)). From 18 to $34 \mathrm{DAP}$, seed moisture content was declining ranging from $11 \%$ (Dr. Pek's 1351) to $22 \%$ (101LTSC-10). The largest reductions of seed moisture content occurred at 38 DAP for all genotypes except for the
C4 inbred line. Overall, C4 inbred line retained the highest seed moisture content among all genotypes throughout seed developments. Unlike seed moisture content, 100-seed weight was gradually increasing during seed development, reaching their maximum values at 34 DAP for 101LTSC-10, C4, THC/H3-7, and P4546/Delec-1 inbred lines and at 30 DAP for Dr. Pek's 1351 hybrid (Figure 1(b)). At this harvest stage, the physiological maturity of each sweet corn genotype could be declared as the maximum 100-seed weight was noticed [34]. However, the seed moisture contents of all tested genotypes remained high ranging from 28.67 to $64.84 \%$. This condition complicated the activities of mechanical shelling that requires relatively low seed moisture content below 35\%. Besides, the balance between seed drying costs and maximum seed yield has normally been the major consideration for determining the proper timing of harvest in corn $[32,35]$. Thus, three inbred lines 101LTSC-10, TSC/H3-7, and P4546/Delec-1 could be harvested during 38-46 DAP when their seed moisture contents were below $35 \%$.

3.2. Changes of Seed Germination and Vigor during Seed Development. During seed developmental stages, seed germination percentage, germination index, mean germination time, and EC value of five corn genotypes showed different patterns, and some genotypes responded the similar patterns (Figure 2). Rapid increases in germination percentage were observed during 18-38 DAP in genotypes TSC/H3-7, 101LTSC-10, and P4546/Delec-1. However, germination percentage seemed to be stable during 38-46 DAP in genotype TSC/H3-7, but gradual declines were noticed in genotypes 101LTSC-10 and P4546/Delec-1 (Figure 2(a)). A similar pattern, C4 inbred line had the highest germination percentage at $42 \mathrm{DAP}$, and then the value was decreasing. Seed producers should harvest sweet 


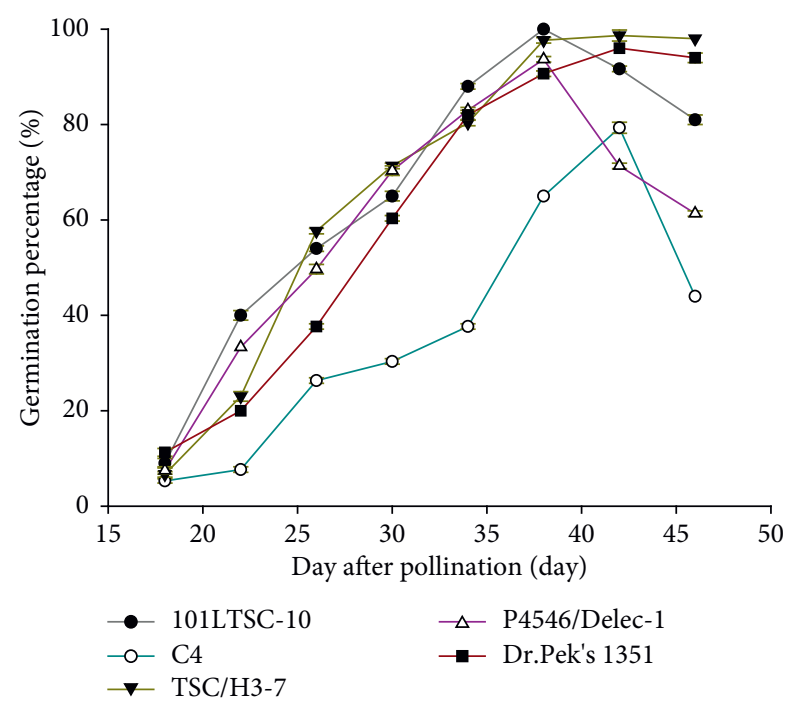

(a)

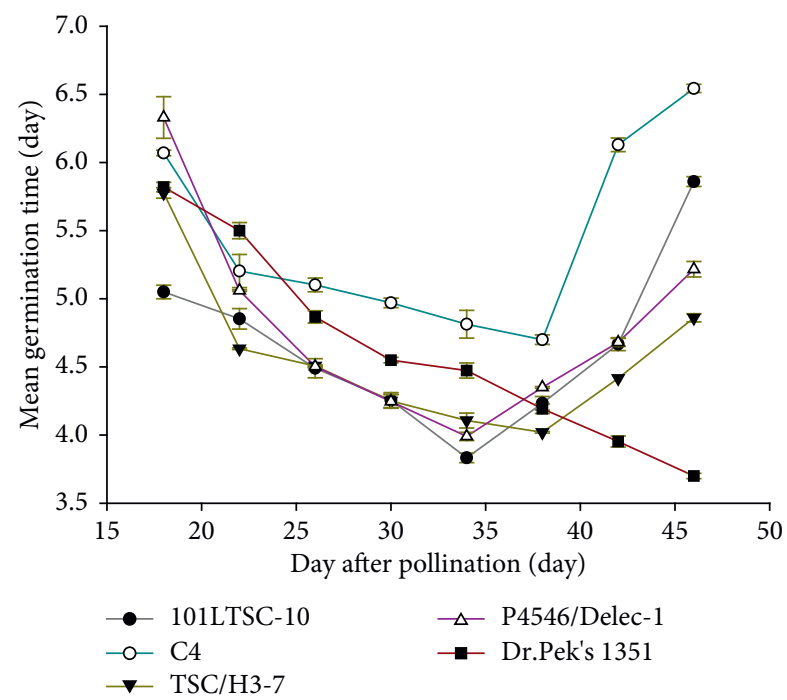

(c)

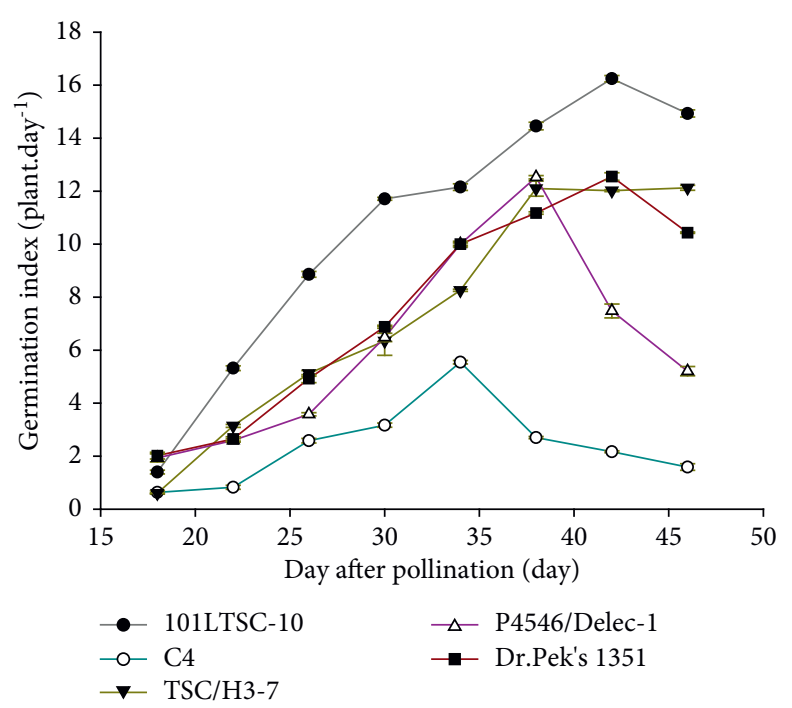

(b)

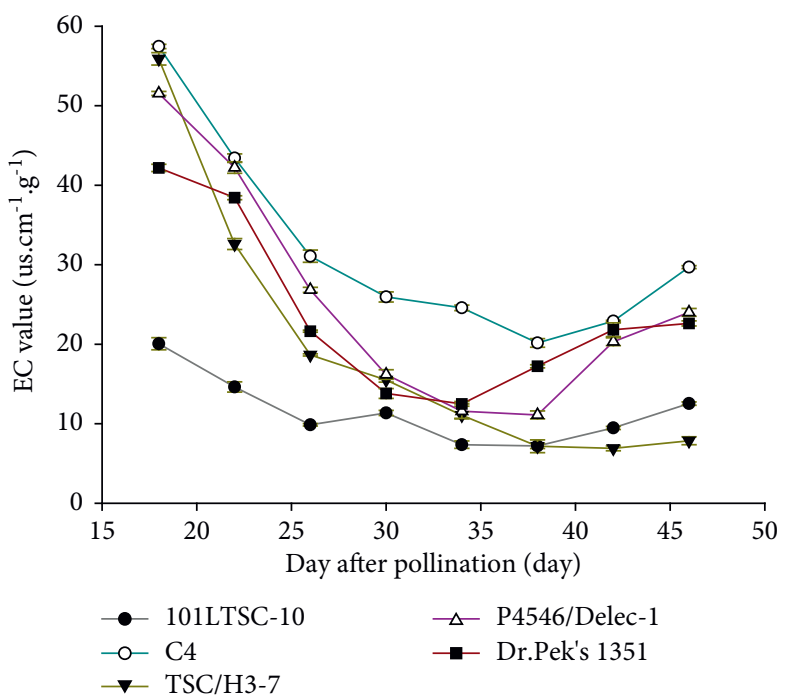

(d)

FIGURE 2: The changes of seed vigor parameters during seed developments of sweet corn: (a) seed germination percentage, (b) germination index, (c) mean germination time, and (d) EC value. The data are means of four replicate samples and error bar \pm SD $(n=4)$.

corn seeds at their optimal maturity date since the postponement of seed harvest contributed to the significant loss of their germinability $[33,34]$. The germination index of each genotype was gradually increasing during seed development, and these values reached the optimum point during 34-42 DAP (Figure 2(b)). On the contrary, mean germination time and EC value were gradually decreasing from 18 to $38 \mathrm{DAP}$ and were increasing afterwards for all genotypes except for Dr. Pek's 1351 hybrid (Figures 2(c)-2(d)).

Previous reports could not clearly elucidate the optimal harvest time for seed production purposes in sweet corn since different hybrids, growing locations, and maturity indices were used [17]. Seed harvest should be performed at the proper seed maturity stage that resulted in high seed vigor. Therefore, understanding the traits associations is essential. In this study, germination percentage, germination index, mean germination time, and EC value were used as a part of parameter indices to predict sweet corn seed vigor at different maturity stages. Seed vigor of the C4 inbred line was distinguishable from other tested genotypes, indicating that seed vigor was strongly influenced by genotypic background. Therefore, seed vigor together with high parental seed yield could be included in the selection criteria to achieve affordable hybrid seed production. In the present study, although there were obvious differences in seed vigor parameters from 30 to $46 \mathrm{DAP}, 38 \mathrm{DAP}$ was considered as the proper harvest timing for genotypes 101LTSC-10, THC/H3-7, and P4546/Delec-1. The other two genotypes C4 inbred line and Dr. Pek's 1351 hybrid were suitable to harvest at 42 DAP. Genotype 101LTSC-10 with triple-recessive genes showed the highest germination percentage and germination index yet low mean 


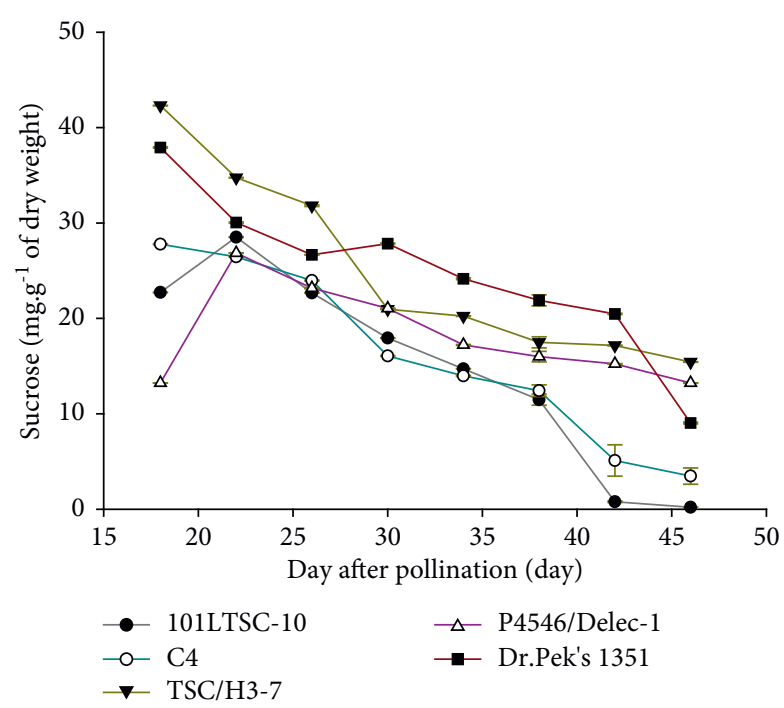

(a)

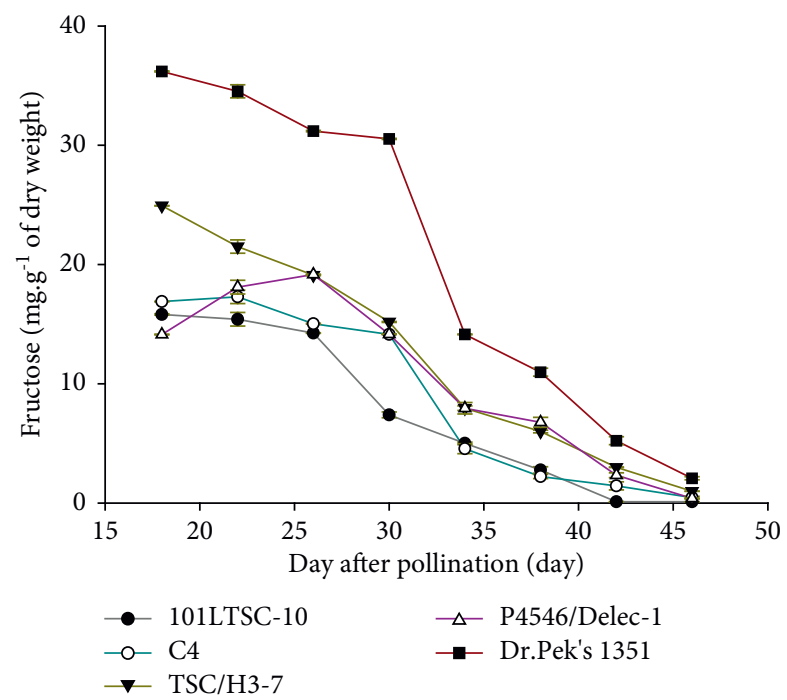

(c)

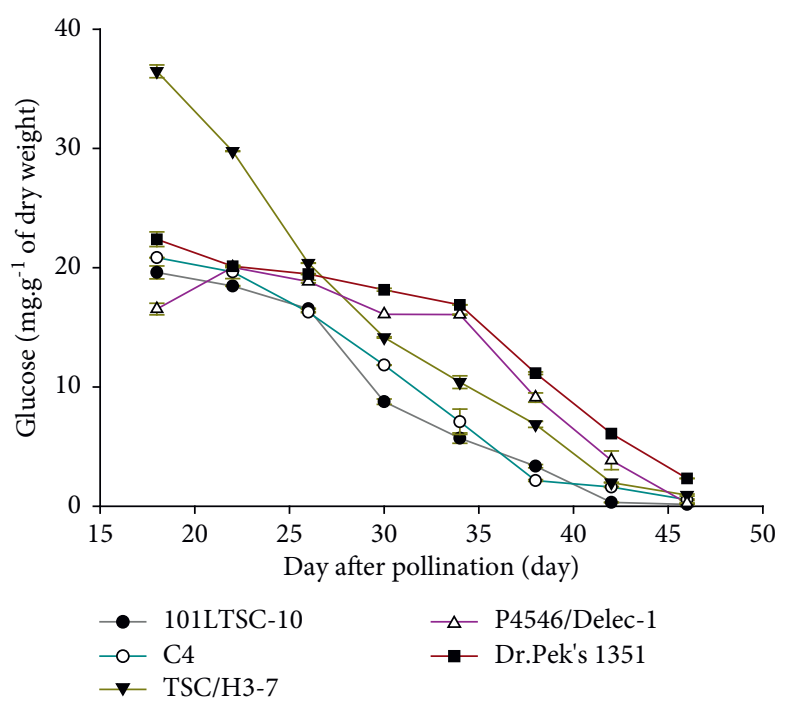

(b)

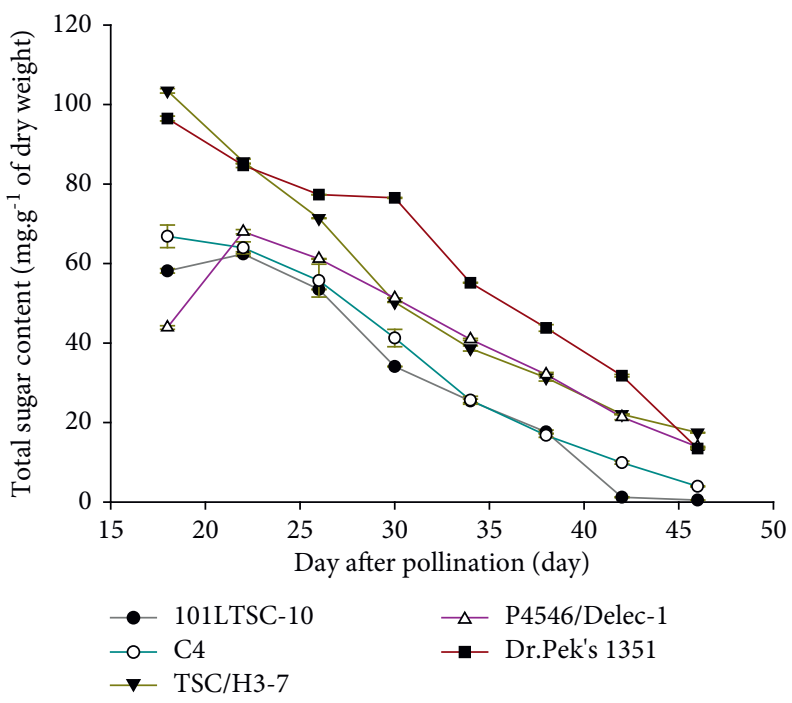

(d)

FIgURE 3: The changes of sugar contents during seed developments of sweet corn: (a) sucrose, (b) glucose, (c) fructose, and (d) total sugar content. The data are means of four replicate samples and error bar \pm SD $(n=4)$.

germination time and EC value. Besides, inbred lines with double-recessive genes had the lowest seed germination and vigor. The result reflected that seed vigor was sensitive to the genetic background. This corroborated a previous study by Pairochteerakul et al. [11], who found that the btbtsh ${ }_{2} \mathrm{sh}_{2} \mathrm{wxwx}$ sweet corn genotype had a higher germination percentage than double-recessive genotypes containing the $w x$ gene. However, they could not clearly propose the optimal maturity date because thorough assessments on these parameters during each seed developmental stage in sweet corn genotypes were not carried out. Low germination of inbred lines with doublerecessive genes could be addressed by seed priming and seedling nursery prior to transplanting in hybrid seed production $[11,12]$. Two single-recessive genotypes TSC/ H3-7 $\left(s h_{2} s h_{2}\right)$ and P4546/Delec-1 (susu) were not different in seed vigor in contrast to Zhao et al. [36] reporting that sweet corn with the $s h_{2}$ gene had higher sugar content than sweet corn with the se gene. Moreover, they noticed that microorganisms could more severely infect the high sugar sweet corn genotype resulting in volatile aldehyde production, which is harmful to seed germination and seedlings. This difference might also be caused by other genetic backgrounds and growing conditions. From our study, it is interesting to note that the EC value is strongly associated with seed quality, suggesting that the EC value is an efficient indicator for seed vigor of sweet corn. This parameter was also suitable for sweet corn $[36,37]$ and other crops including pea [38], sorghum [39], and safflower [40]. However, Zhao et al. [36] reported that the EC test was only reliable to estimate the seed vigor of sweet corn with the se gene. 


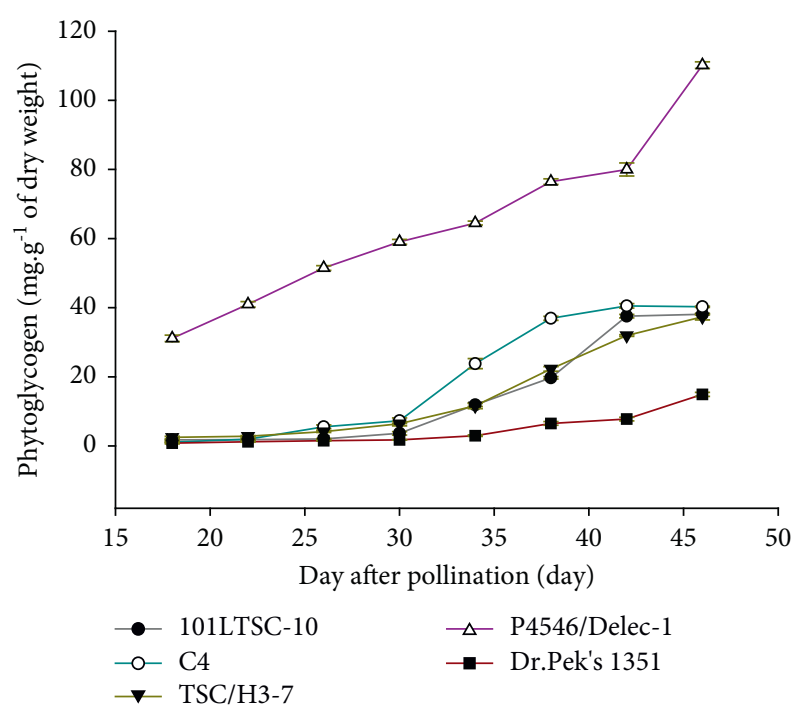

(a)

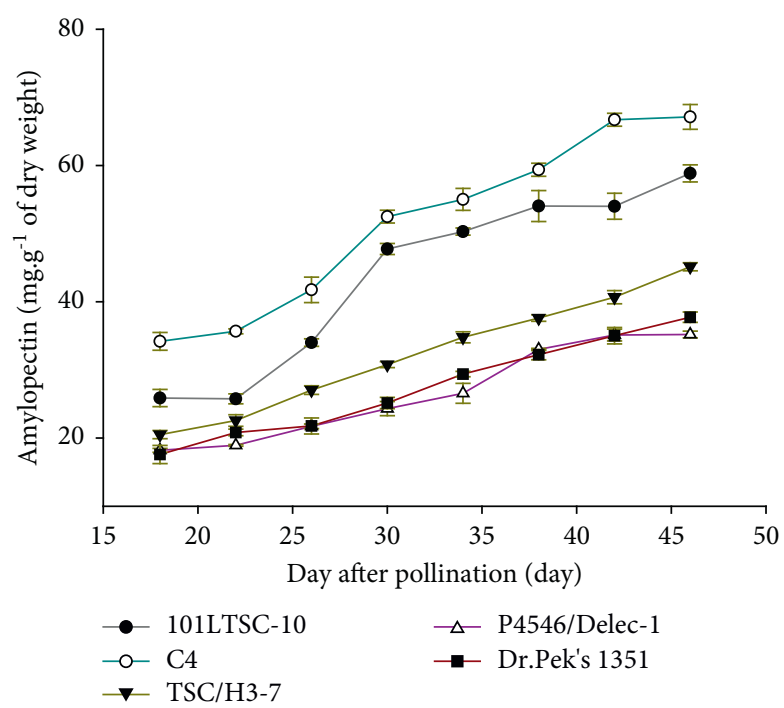

(b)

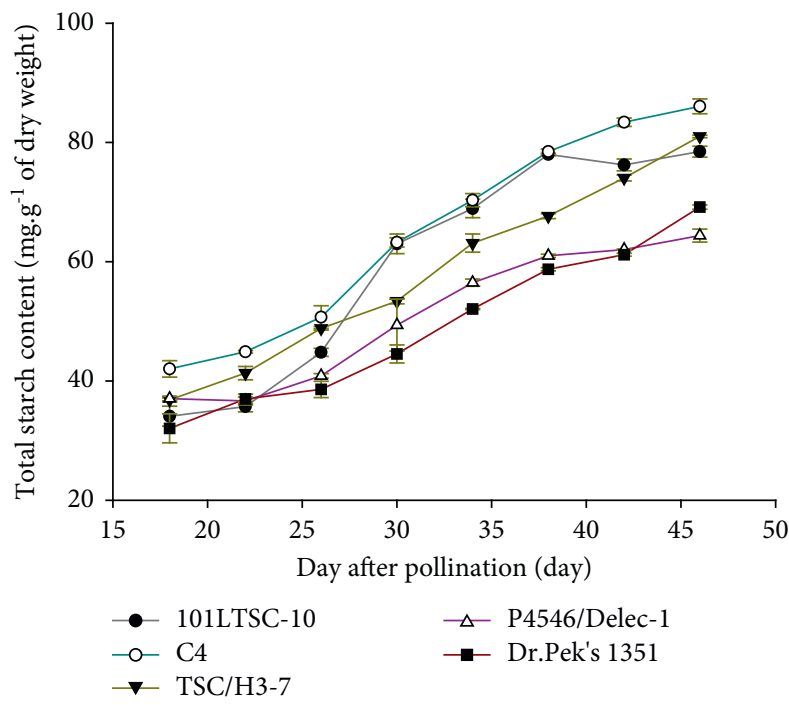

(c)

Figure 4: The changes of starch contents in sweet corn seeds during seed development: (a) phytoglycogen, (b) amylopectin, and (c) total starch content. The data are means of four replicate samples and error bar \pm SD $(n=4)$.

\subsection{Changes of Sugar and Starch Contents in Sweet Corn Seeds} during Seed Development. At an immature stage, the type of sweet corn (inbred line or hybrid) did not determine the carbohydrate compositions, but the differences in these characters were mainly genotype-dependent. Inbred line (TSC/H3-7) and hybrid cultivar (Dr. Pek's 1351) with a single-recessive genotype $\left(s h_{2} s h_{2}\right)$ had higher sugar content than P4546/Delec-1 (susu) and double- or triple-recessive gene genotypes (Figures 3(a)-3(d)). P4546/Delec-1 (susu) had higher phytoglycogen content than other genotypes (Figure 4(a)). This result indicated that $s h_{2}$ sweet corn genotypes could retain high contents of sugar fractions whereas $s u$ genotypes retained high phytoglycogen content. As a comparison, mutant (sugary-1, su1) crops, including corn and rice, showed relatively high phytoglycogen content [41, 42]. Meanwhile, double- and triple-recessive gene combinations resulted in the highest amylopectin and total starch contents during seed development (Figures 4(b) and 4(c)). Ketthaisong et al. [43] and Simla et al. [25] reported that $w x$ corn genotypes comprise more than $80 \%$ amylopectin starch.

The types of reserves accumulated in the endosperm of developing seeds have many potential roles such as seed establishment and autotrophic developmental stage that foster initial seedling survival under various field conditions [24]. The changes in carbohydrate compositions and concentrations in sweet corn and other corn types during seed development have been reported [24, 44]. However, changes in sugar and starch contents during seed developmental stages of synergistic sweet corn genotypes have not been reported. In the present study, five sweet corn genotypes differed in their seed carbohydrate characters including sucrose, glucose, fructose, total sugar, phytoglycogen, 
TABLE 2: Regression equations between seed quality and carbohydrate characters during seed developments of sweet corn.

\begin{tabular}{|c|c|c|c|}
\hline $\begin{array}{l}\text { Inbreds/ } \\
\text { hybrid }\end{array}$ & arameters & Regression equations & $R^{2}$ \\
\hline \multirow{4}{*}{$\begin{array}{l}\text { 101LTSC- } \\
10\end{array}$} & GP & $\begin{array}{c}Y=121.902-0.568 X_{11}-28.876 X_{2}+33.009 X_{3}-0.100 X_{4}-5.362 X_{5}+4.787 X_{6}\left(b_{0}=0.137 ; b_{1}=0.137 ;\right. \\
\left.b_{2}=0.006 ; b_{3}=0.007 ; b_{4}=0.581 ; b_{5}=0.005 ; b_{6}=0.006\right)\end{array}$ & 0.950 \\
\hline & GI & $\begin{array}{c}Y=-11.367-1.345 X_{1}-4.916 X_{2}+3.127 X_{3}+1.352 X_{4}-0.060 X_{5}+3.061 X_{6}\left(b_{0}=0.769 ; b_{1}=0.430\right. \\
\left.b_{2}=0.274 ; b_{3}=0.493 ; b_{4}=0.441 ; b_{5}=0.901 ; b_{6}=0.015\right)\end{array}$ & 0.990 \\
\hline & MGT & $\begin{array}{c}Y=33.156+0.888 X_{1}-0.536 X_{2}+2.512 X_{3}-1.137 X_{4}-3.026 X_{5}-5.104 X_{6}\left(b_{0}=0.050 ; b_{1}=0.100\right. \\
\left.b_{2}=0.252 ; b_{3}=0.080 ; b_{4}=0.083 ; b_{5}=0.050 ; b_{6}=0.041\right)\end{array}$ & 0.909 \\
\hline & $\mathrm{EC}$ & $\begin{array}{c}Y=58.586+0.120 X_{1}+0.075 X_{2}+1.250 X_{3}-0.773 X_{4}+1.023 X_{5}-1.333 X_{6}\left(b_{0}=0.044 ; b_{1}=0.977 ;\right. \\
\left.b_{2}=0.933 ; b_{3}=0.920 ; b_{4}=0.862 ; b_{5}=0.050 ; b_{6}=0.048\right)\end{array}$ & 0.956 \\
\hline \multirow{4}{*}{$\mathrm{C} 4$} & GP & $\begin{array}{c}Y=239.896+16.535 X_{1}+6.297 X_{2}+16.918 X_{3}-5.138 X_{4}-1.294 X_{5}-1.370 X_{6}\left(b_{0}=0.026 ; b_{1}=0.013 ;\right. \\
\left.b_{2}=0.303 ; b_{3}=0.006 ; b_{4}=0.436 ; b_{5}=0.077 ; b_{6}=0.014\right)\end{array}$ & 0.962 \\
\hline & GI & $\begin{array}{c}Y=-53.865+1.007 X_{1}+0.485 X_{2}-0.076 X_{3}-0.134 X_{4}-1.717 X_{5}+1.059 X_{6}\left(b_{0}=0.028 ; b_{1}=0.049\right. \\
\left.b_{2}=0.612 ; b_{3}=0.846 ; b_{4}=0.801 ; b_{5}=0.045 ; b_{6}=0.048\right)\end{array}$ & 0.993 \\
\hline & MGT & $\begin{array}{c}Y=37.957-0.851 X_{1}-0.587 X_{2}-0.194 X_{3}-0.326 X_{4}+0.439 X_{5}+3.144 X_{6}\left(b_{0}=0.035 ; b_{1}=0.464 ;\right. \\
\left.b_{2}=0.675 ; b_{3}=0.726 ; b_{4}=0.680 ; b_{5}=0.387 ; b_{6}=0.023\right)\end{array}$ & 0.717 \\
\hline & $\mathrm{EC}$ & $\begin{array}{c}Y=242.884-15.349 X_{1}-12.365 X_{2}-7.656 X_{3}+9.392 X_{4}-5.395 X_{5}-3.333 X_{6}\left(b_{0}=0.323 ; b_{1}=0.028\right. \\
\left.b_{2}=0.042 ; b_{3}=0.296 ; b_{4}=0.348 ; b_{5}=0.356 ; b_{6}=0.534\right)\end{array}$ & 0.909 \\
\hline \multirow{4}{*}{ TSC/H3-7 } & GP & $\begin{array}{c}Y=196.365-10.760 X_{1}-15.779 X_{2}-12.687 X_{3}+11.668 X_{4}+1.589 X_{5}-2.226 X_{6}\left(b_{0}=0.165 ; b_{1}=0.147\right. \\
\left.b_{2}=0.091 ; b_{3}=0.119 ; b_{4}=0.123 ; b_{5}=0.712 ; b_{6}=0.529\right)\end{array}$ & 0.998 \\
\hline & GI & $\begin{array}{c}Y=0.665-2.271 X_{1}-2.193 X_{2}-2.017 X_{3}+2.127 X_{4}-1.116 X_{5}+0.791 X_{6}\left(b_{0}=0.987 ; b_{1}=0.384 ; b_{2}=0.361\right. \\
\left.b_{3}=0.403 ; b_{4}=0.374 ; b_{5}=0.678 ; b_{6}=0.6931\right)\end{array}$ & 0.909 \\
\hline & MGT & $\begin{array}{c}Y=10.503-0.501 X_{1}-0.337 X_{2}+0.153 X_{3}-0.326 X_{4}+0.841 X_{5}+0.460 X_{6}\left(b_{0}=0.024 ; b_{1}=0.191\right. \\
\left.b_{2}=0.252 ; b_{3}=0.491 ; b_{4}=0.283 ; b_{5}=0.151 ; b_{6}=0.203\right)\end{array}$ & 0.993 \\
\hline & EC & $\begin{array}{c}Y=95.160+7.991 X_{1}+5.523 X_{2}-1.224 X_{3}-4.721 X_{4}+16.616 X_{5}-10.884 X_{6}\left(b_{0}=0.457 ; b_{1}=0.299 ;\right. \\
\left.b_{2}=0.369 ; b_{3}=0.803 ; b_{4}=0.420 ; b_{5}=0.194 ; b_{6}=0.219\right)\end{array}$ & 0.995 \\
\hline \multirow{4}{*}{$\begin{array}{l}\text { P4546/ } \\
\text { Delec-1 }\end{array}$} & GP & $\begin{array}{c}Y=-291.594-3.652 X_{1}+0.387 X_{2}+0.451 X_{3}-3.041 X_{4}+2.542 X_{5}+4.214 X_{6}\left(b_{0}=0.057 ; b_{1}=0.474\right. \\
\left.b_{2}=0.916 ; b_{3}=0.853 ; b_{4}=0.455 ; b_{5}=0.350 ; b_{6}=0.149\right)\end{array}$ & 0.998 \\
\hline & GI & $\begin{array}{c}Y=-45.084-2.726 X_{1}-0.920 X_{2}-1.303 X_{3}+1.900 X_{4}-0.901 X_{5}+0.450 X_{6}\left(b_{0}=0.066 ; b_{1}=0.138\right. \\
\left.b_{2}=0.329 ; b_{3}=0.165 ; b_{4}=0.154 ; b_{5}=0.242 ; b_{6}=0.6931\right)\end{array}$ & 0.996 \\
\hline & MGT & $\begin{array}{c}Y=1.503-0.501 X_{1}-0.337 X_{2}+0.153 X_{3}-0.326 X_{4}+0.841 X_{5}+0.060 X_{6}\left(b_{0}=0.024 ; b_{1}=0.191 ; b_{2}=0.252 ;\right. \\
\left.b_{3}=0.491 ; b_{4}=0.283 ; b_{5}=0.151 ; b_{6}=0.169\right)\end{array}$ & 0.990 \\
\hline & $\mathrm{EC}$ & $\begin{array}{c}Y=95.160+7.991 X_{1}+5.523 X_{2}-1.224 X_{3}-4.721 X_{4}+6.616 X_{5}-1.884 X_{6}\left(b_{0}=0.457 ; b_{1}=0.299 ;\right. \\
\left.b_{2}=0.369 ; b_{3}=0.803 ; b_{4}=0.420 ; b_{5}=0.134 ; b_{6}=0.982\right)\end{array}$ & 0.998 \\
\hline \multirow{4}{*}{$\begin{array}{l}\text { Dr. Pek's } \\
1351\end{array}$} & GP & $\begin{array}{c}Y=17.374-2.394 X_{1}+4.318 X_{2}-0.441 X_{3}-7.201 X_{4}+4.807 X_{5}-1.345 X_{6}\left(b_{0}=0.007 ; b_{1}=0.582 ;\right. \\
\left.b_{2}=0.317 ; b_{3}=0.709 ; b_{4}=0.077 ; b_{5}=0.690 ; b_{6}=0.787\right)\end{array}$ & 0.996 \\
\hline & GI & $\begin{array}{c}Y=-36.506+0.299 X_{1}+0.435 X_{2}-0.048 X_{3}+0.466 X_{4}-0.349 X_{5}-0.081 X_{6}\left(b_{0}=0.030 ; b_{1}=0.285\right. \\
\left.b_{2}=0.202 ; b_{3}=0.620 ; b_{4}=0.074 ; b_{5}=0.609 ; b_{6}=0.776\right)\end{array}$ & 0.998 \\
\hline & MGT & $\begin{array}{c}Y=-0.545-0.044 X_{1}-0.093 X_{2}+0.032 X_{3}-1.00 X_{4}+0.083 X_{5}+0.095 X_{6}\left(b_{0}=0.974 ; b_{1}=0.714 ; b_{2}=0.494\right. \\
\left.b_{3}=0.601 ; b_{4}=0.557 ; b_{5}=0.836 ; b_{6}=0.611\right)\end{array}$ & 0.976 \\
\hline & EC & $\begin{array}{c}Y=70.044-0.032 X_{1}-5.056 X_{2}-1.234 X_{3}+1.753 X_{4}-8.040 X_{5}-3.505 X_{6}\left(b_{0}=0.900 ; b_{1}=0.993 ;\right. \\
\left.b_{2}=0.344 ; b_{3}=0.558 ; b_{4}=0.737 ; b_{5}=0.585 ; b_{6}=0.578\right)\end{array}$ & 0.923 \\
\hline
\end{tabular}

Note: GP, germination percentage; GI, germination index; MGT, mean germination time; and EC, electrical conductivity. $X_{1}, X_{2}, X_{3}, X_{4}, X_{5}$, and $X_{6}$ were sucrose, glucose, fructose, total sugar content, amylopectin, and total starch content, respectively; $b_{0}, b_{1}, b_{2}, b_{3}, b_{4}, b_{5}$, and $b_{6}$ were $P$ values for intercept, $X_{1}, X_{2}$, $X_{3}, X_{4}, X_{5}$, and $X_{6}$, respectively.

amylopectin, and total starch (Figure 3). These variations on seed carbohydrate profiles contributed to the seed vigor, and the optimal harvest time of each sweet corn genotype was different. Sucrose was the most abundant soluble saccharide among all sugar fractions of the endosperm. This fraction peaked at 18 DAP for three genotypes $\mathrm{C} 4$, THC/H3-7, and Dr. Pek's 1351 and at 22 DAP for two inbred lines 101LTSC10 and P4546/Delec-1 (Figure 3(a)). After the endosperm sucrose reached the maximum values, this content rapidly decreased from milk (18-20 DAP) to physiological maturity stages. However, these reductions varied depending upon genotype. Glucose, fructose, and total sugar contents were likewise decreasing after surpassing the maximum values (Figures 3(b)-3(d)). This finding confirmed that the contents of both total sugar and sugar fractions started increasing at a post-pollination stage, reached the peak values at the milk stage, started decreasing afterwards, and were at the lowest values at the physiological maturity stage $[45,46]$. However, incorporation of the $w x$ recessive gene into synergistic sweet corn backgrounds (BtBtsh $h_{2} h_{2} w x w x$ and $b t b t s h_{2} s h_{2} w x w x$ ) resulted in low sugar contents during most seed developmental stages. In contrast to our finding, Pairochteerakul et al. [11] reported that sweet corn genotypes with $B t B t s h_{2} s h_{2} w x w x$ background showed high sugar contents at immature and mature stages than genotypes $b t b t s h_{2} s h_{2} w x w x$ and $B t B t s h_{2} s h_{2} W x W x$. This opposite finding might be due to different experimental conditions and even the methods of sugar quantification. 
TABLE 3: Regression equations between seed quality and total starch contents in sweet corn seeds during seed development.

\begin{tabular}{|c|c|c|c|}
\hline Inbreds/Hybrid & Parameters & Regression equations & $R^{2}$ \\
\hline 101LTSC-10 & $\begin{array}{l}\text { GP } \\
\text { GI } \\
\text { MGT } \\
\text { EC }\end{array}$ & $\begin{array}{c}Y=-24.361+1.510 X_{6}\left(b_{0}=0.156 ; b_{6}=0.001\right) \\
Y=-4.909+0.259 X_{6}\left(b_{0}=0.050 ; b_{6}=0\right) \\
Y=5.572-0.021 X_{6}\left(b_{0}=0.003 ; b_{6}=0.027\right) \\
Y=20.316-0.138 X_{6}\left(b_{0}=0.001 ; b_{6}=0.029\right)\end{array}$ & $\begin{array}{l}0.868 \\
0.915 \\
0.597 \\
0.575\end{array}$ \\
\hline $\mathrm{C} 4$ & $\begin{array}{l}\text { GP } \\
\text { GI } \\
\text { MGT } \\
\text { EC }\end{array}$ & $\begin{array}{c}Y=-52.980+1.414 X_{6}\left(b_{0}=0.012 ; b_{6}=0.001\right) \\
Y=-1.908+0.068 X_{6}\left(b_{0}=0.329 ; b_{6}=0.044\right) \\
Y=5.190-0.004 X_{6}\left(b_{0}=0.003 ; b_{6}=0.024\right) \\
Y=71.357-0.621 X_{6}\left(b_{0}=0.001 ; b_{6}=0.009\right)\end{array}$ & $\begin{array}{l}0.865 \\
0.518 \\
0.559 \\
0.760 \\
\end{array}$ \\
\hline TSC/H3-7 & $\begin{array}{l}\text { GP } \\
\text { GI } \\
\text { MGT } \\
\text { EC }\end{array}$ & $\begin{array}{c}Y=-56.205+2.109 X_{6}\left(b_{0}=0.025 ; b_{6}=0.001\right) \\
Y=-8.413+0.272 X_{6}\left(b_{0}=0.003 ; b_{6}=0\right) \\
Y=5.511-0.016 X_{6}\left(b_{0}=0 ; b_{6}=0.025\right) \\
Y=72.949-0.918 X_{6}\left(b_{0}=0.002 ; b_{6}=0.008\right)\end{array}$ & $\begin{array}{l}0.881 \\
0.941 \\
0.725 \\
0.721 \\
\end{array}$ \\
\hline P4546/Delec-1 & $\begin{array}{c}\text { GP } \\
\text { GI } \\
\text { MGT } \\
\text { EC } \\
\end{array}$ & $\begin{array}{c}Y=-33.996+1.866 X_{6}\left(b_{0}=0.103 ; b_{6}=0.002\right) \\
Y=-5.873+0.237 X_{6}\left(b_{0}=0.242 ; b_{6}=0.034\right) \\
Y=6.366-0.032 X_{6}\left(b_{0}=0 ; b_{6}=0.031\right) \\
Y=74.370-0.595 X_{6}\left(b_{0}=0.005 ; b_{6}=0.027\right)\end{array}$ & $\begin{array}{l}0.830 \\
0.554 \\
0.537 \\
0.584 \\
\end{array}$ \\
\hline Dr. Pek's 1351 & $\begin{array}{l}\text { GP } \\
\text { GI } \\
\text { MGT } \\
\text { EC }\end{array}$ & $\begin{array}{c}Y=-63.292+2.548 X_{6}\left(b_{0}=0.007 ; b_{6}=0\right) \\
Y=-9.056+0.349 X_{6}\left(b_{0}=0 ; b_{6}=0\right) \\
Y=7.236-0.053 X_{6}\left(b_{0}=0 ; b_{6}=0\right) \\
Y=58.062-0.691 X_{6}\left(b_{0}=0.003 ; b_{6}=0.025\right)\end{array}$ & $\begin{array}{l}0.919 \\
0.975 \\
0.904 \\
0.593\end{array}$ \\
\hline
\end{tabular}

Note: GP, germination percentage; GI, germination index; MGT, mean germination time; and EC, electrical conductivity. $X_{6}$ was total starch content; $b_{0}$ and $b_{6}$ were $P$ values for intercept and $X_{6}$, respectively.

In contrast to sugar, the starch contents of all genotypes were increasing following the prolonged harvest period. Rapid increases in phytoglycogen were observed during 18-46 DAP in the C4 inbred line (Figure 4(a)). On the contrary, the phytoglycogen of genotypes 101LTSC10, C4, THC/H3-7, P4546/Delec-1, and Dr. Pek's 1351 was slightly increased from 18 to $30 \mathrm{DAP}$, and the rapid increment was noticed afterwards. Both amylopectin and total starch contents of sweet corn genotypes followed a similar pattern of their phytoglycogen (Figures 4(b) and 4(c). Sugar gradually converted to starch during the development of kernel endosperm [21]. These changes were caused by the activities of key starch biosynthetic enzymes including UDP-glucose pyrophosphorylase, ADP-glucose pyrophosphorylase, hexokinase, granule bound starch synthase, and soluble starch synthase during corn endosperm formation [47, 48]. Starch biosynthetic enzyme activities were rapidly increasing after 12 DAP and reached the maximum levels at 20-22 DAP [48]. Both previous reports and our result confirmed that the contents of carbohydrate characters during seed development were based on genes controlling endosperm.

3.4. Regression Analysis between Carbohydrate Characters and Seed Quality during Seed Development of Sweet Corn Genotypes. Time series regression (TSR) analysis has been applied to assess the seed quality of sweet corn by considering seed size and endogenous polyamines [15, 22]. In our study, seed carbohydrate characters were included in TSR analysis to estimate the seed quality of five sweet corn genotypes from 18 to 46 DAP. Since phytoglycogen did not contribute to the equation, this variable was then omitted for the analysis. Carbohydrate contents contributed to the seed germination of synergistic sweet corn lines; however, no distinctive regression relationship was observed between carbohydrate contents and seed germination in any singlerecessive gene genotype tested in this study. Among eight equations of triple- and double-recessive genes, $X_{6}$ (total starch content) in 7 equations, $X_{5}$ (amylopectin) in 4 equations, $X_{1}$ (sucrose) in 3 equations, and $X_{2}$ (glucose), and $X_{3}$ (fructose) in 2 equations had a significant contribution to the corresponding equations, whereas $X_{4}$ (total sugar content) did not contribute to all equations (Table 2). The total starch content of the significant equations was $75 \%$ more contributed than the other 5 variables. The equations with significant starch content had a regression coefficient $\left(R^{2}\right)$ ranging from 0.717 to 0.993 , suggesting that the equations had a stronger responsibility level with data, and total starch content was the key factor affecting seed germination and vigor. Simpler equations were developed by using TSR when some factors with minor effects on seed germination were eliminated (Table 3). Total starch content had significant contributions $(P \leq 0.05)$ to all equations. Although regression coefficient values slightly changed, these equations were easier to be used. Moreover, all coefficients of total starch were positive to estimate germination percentage and germination index, indicating that seed vigor could be predicted by the total starch content during seed developmental stages in synergistic sweet corn and that vigorous seeds would have a higher total starch content. Besides, we utilized the TSR equations to classify carbohydrate accumulation during seed development. This corroborated previous reports that modeled the seed developmental process by the TSR's equation $[15,21,22]$. However, seed vigor is a complex agronomic trait that is necessary to be determined the factors as does the effect of the genetic and biochemical processes 
studied during seed development. Moreover, the seed industry needs a rapid and nondestructive evaluation method for seed germination. This will be the subject of further investigations.

\section{Conclusions}

Genes controlling endosperm altered carbohydrate characters and seed vigor during seed development of sweet corn genotypes. Proper harvest date for triple-recessive genotype (btbtsh $\left.{ }_{2} \mathrm{sh}_{2} w x w x\right)$ and single-recessive genotypes (BtBtsh ${ }_{2} \mathrm{sh}_{2} W x W x$ and $S h_{2} S h_{2}$ susu $\left.W x W x\right)$ was 38 DAP whereas that for double-recessive genotype $\left(B t B t s h_{2} s h_{2} w x w x\right)$ was 42 DAP. The TSR analysis was effective to predict germination percentage and germination index when total starch contents were positive. Moreover, total starch content was the optimal index for assessing the seed germination and vigor of synergistic super sweet corn inbred lines.

\section{Data Availability}

The data that support the findings of this study are available from the corresponding author upon reasonable request.

\section{Conflicts of Interest}

The authors declare that there are no conflicts of interest.

\section{Acknowledgments}

The authors gratefully acknowledge the financial support provided by the Faculty of Science and Technology, Thammasat University (grant no. SciGR24/2563). Acknowledgment is also extended to the Department of Agricultural Technology, Faculty of Science and Technology, Thammasat University and Plant Breeding Research Center for Sustainable Agriculture, Khon Kaen University for providing research facilities, and Mr. Abil Dermail for proofreading the manuscript.

\section{References}

[1] F. Azanza, A. Bar-Zur, and J. A. Juvik, "Variation in sweet corn kernel characteristics associated with stand establishment and eating quality," Euphytica, vol. 87, pp. 7-18, 1996.

[2] H. Ciu, Z. Cheng, P. Li, and A. Miao, "Prediction of sweet corn seed germination based on hyperspectral image technology and multivariate data regression," Sensors, vol. 20, no. 17, Article ID 4744, 2020.

[3] P. Ravilla, C. M. Anibas, and W. F. Tracy, "Sweet corn research around the world 2015-2020," Agronomy, vol. 11, no. 3, Article ID 534, 2021.

[4] FAOSTAT, Crops and Livestock Products, FAO, Rome, Italy, 2019, https://www.fao.org/faostat/en/\#data/QCL.

[5] V. Ruanjaichon, K. Khammona, B. Thunnom et al., "Identification of gene associated with sweetness in corn (Zea mays L.) by genome-wide association study (GWAS) and development of a functional SNP marker for predicting sweet corn," Plants, vol. 10, no. 9, Article ID 1239, 2021.
[6] W. F. Tracy, Specialty Corns, A. R. Hallauer, Ed., CRC Press, Boca Raton, FL, USA, 2nd edition, 2001.

[7] K. Lertrat and T. Pulam, "Breeding for increased sweetness in sweet corn," International Journal of Plant Breeding and Genetics, vol. 1, no. 1, pp. 27-30, 2017.

[8] K. Lertrat and N. Thongnarin, "Novel approach to eating quality improvement in local waxy corn: improvement of sweet taste in local waxy corn variety with mixed kernels from super sweet corn," Acta Horticulturae, vol. 769, pp. 145-150, 2008.

[9] S. Simla, K. Lertrat, and B. Suriharn, "Combinations of multiple genes controlling endosperm characters in relation to maximum eating quality of vegetable waxy corn," SABRAO Journal of Breeding and Genetics, vol. 48, no. 2, pp. 210-218, 2016.

[10] A. Fuengtee, A. Dermail, S. Simla et al., "Combining ability for carbohydrate components associated with consumer preferences in tropical sweet and waxy corn derived from exotic germplasm," Turkish Journal of Field Crops, vol. 25, no. 1, pp. $147-155,2020$.

[11] P. Pairochteerakul, D. Jothityangkoon, D. Ketthaisong, and S. Simla, "Seed germination in relation to total sugar and starch in endosperm mutant of sweet corn genotypes," Agronomy, vol. 8, no. 12, Article ID 299, 2018.

[12] S. Simla, K. Lertrat, and B. Suriharn, "Germination behavior of five genotypic different of immature vegetable corn seed and in response to hydro-priming," Seed Science and Biotechnology, vol. 3, no. 2, pp. 64-68, 2009.

[13] X. Wu, F. Ning, X. Hu, and W. Wang, "Genetic modification for improving seed vigor is transitioning from model plants to crop plants," Frontiers in Plant Science, vol. 8, Article ID 2998, 2017.

[14] S. Pedrini, A. Balestrazzi, M. D. Madsen et al., "Seed enhancement: getting seeds restoration-ready," Restoration Ecology, vol. 28, no. S3, pp. S266-S275, 2020.

[15] D. D. Cao, J. Hu, S. J. Zhu, W. M. Hu, and A. Knapp, "Relationship between changes in endogenous polyamines and seed quality during development of sh2 sweet corn (Zea mays L.) seed," Scientia Horticulturae, vol. 123, no. 3, pp. 301-307, 2010.

[16] Z. Han, L. Ku, Z. Zhang et al., "QTLs for seed vigor-related traits identified in maize seeds germinated under artificial aging conditions," PLoS One, vol. 9, no. 9, Article ID e92535, 2014.

[17] A. M. Borowski, V. A. Fritz, and L. Waters, "Seed maturity influences germination and vigor of two shrunken-2 sweet corn hybrids," Journal of the American Society for Horticultural Science, vol. 116, no. 3, pp. 401-404, 1991.

[18] V. O. Adetimirin, S. K. Kim, and M. Szczech, "Factors associated with emergence of shrunken-2 maize in Korea," Journal of Agricultural Science, vol. 144, no. 1, pp. 63-68, 2006.

[19] X. Wang, H. Zheng, Q. Tang, Q. Chen, and W. Mo, "Seed filling under different temperatures improves the seed vigor of hybrid rice (Oryza sativa L.) via starch accumulation and structure," Scientific Reports, vol. 10, Article ID 563, 2020.

[20] A. M. Borowski, V. A. Fritz, and L. Waters, "Seed maturity and desiccation affect carbohydrate composition and leachate conductivity in shrunken-2 sweet corn," HortScience, vol. 30, no. 7, pp. 1396-1399, 1995.

[21] D.-D. Cao, J. Hu, X.-X. Huang, X.-J. Wang, Y.-J. Guan, and Z.-F. Wang, "Relationships between changes of kernel nutritive components and seed vigor during development stages of F1 seeds of sh 2 sweet corn," Journal of Zhejiang UniversityScience B, vol. 9, no. 12, pp. 964-968, 2008. 
[22] Y. J. Guan, J. Hu, Z. F. Wang, S. J. Zhu, J. C. Wang, and A. Knapp, “Time series regression analysis between changes in kernel size and seed vigor during developmental stage of sh2 sweet corn (Zea mays L.) seeds," Scientia Horticulturae, vol. 154, pp. 25-30, 2013.

[23] C. Bailly, C. Audigier, F. Ladonne et al., "Changes in oligosaccharide content and antioxidant enzyme activities in developing bean seeds as related to acquisition of drying tolerance and seed quality," Journal of Experimental Botany, vol. 52, no. 357, pp. 701-708, 2001.

[24] L. Wang, J. W. Patrick, and Y. L. Ruan, "Live long and prosper: roles of sugar and sugar polymers in seed vigor," Molecular Plant, vol. 11, no. 1, pp. 1-3, 2013.

[25] S. Simla, K. Lertrat, and B. Suriharn, "Carbohydrate characters of six vegetable waxy corn varieties as affected by harvest time and storage duration," Asian Journal of Plant Science, vol. 9, no. 9, pp. 463-470, 2009.

[26] National Bureau of Agricultural Commodity and Food Standards and Ministry of Agriculture and Cooperatives, "Good Agricultural Practices For Sweet Corn, Bangkok, Thailand," 2014, https://www.acfs.go.th.

[27] International Seed Testing Associate, "International Rules for Seed Testing," Seed Science and Technology, vol. 27, 2007.

[28] Q. Cao, G. Li, Z. Cui et al., "Seed priming with melatonin improves the seed germination of waxy maize under chilling stress via promoting the antioxidant system and starch metabolism," Scientific Reports, vol. 9, Article ID 15044, 2019.

[29] K. A. Gomaz and A. A. Gomez, Statistical Procedures for Agricultural Research, John Wiley \& Sons, Hoboken, NJ, USA, 2nd edition, 1984.

[30] D. J. Murphy and I. Cummins, "Biosynthesis of seed storage products during embryogenesis in rapeseed, Brassica napus, Brassica napus," Journal of Plant Physiology, vol. 135, no. 1, pp. 63-69, 1989.

[31] C. W. Culpepper and C. H. Moon, "Effect of state of maturity at time of harvest on germination of sweet corn," Journal of Agricultural Research, vol. 3, no. 6, pp. 335-343, 1941.

[32] R. G. Sala, F. H. Andrade, and M. E. Westgate, "Maize kernel moisture at physiological maturity as affected by the sourcesink relationship during grain filling," Crop Science, vol. 47, no. 2, pp. 711-714, 2007.

[33] E. A. Jacob Junior, L. M. Mertz, F. A. Henning, S. T. Peske, F. A. Villela, and L. M. B. Labbé, "Ideal seeds harvest moment of different maize hybrids," Ciência Rural, vol. 44, no. 2, pp. 253-260, 2014.

[34] S. R. Aldrich, "Maturity measurements in corn and an indication that grain development continues after premature cutting 1," Agronomy Journal, vol. 35, no. 8, pp. 667-680, 1943.

[35] H. R. Mloza-Banda, "Seed Maturation and Drying in Sweet Corn (Zea mays L.) Endosperm Mutants," Ph. D. Thesis, Department of Agronomy, Iowa State University, Ames, USA, 1992.

[36] G. W. Zhao, Q. Sun, and J. H. Wang, "Improving seed vigour assessment of super sweet and sugar-enhanced sweet corn (Zea mays saccharata)," New Zealand Journal of Crop and Horticultural Science, vol. 35, no. 3, pp. 349-356, 2007.

[37] W. Santipracha, Q. Santiprachan, and V. Wongvarodom, "Hybrid corn seed quality and accelerated aging," Seed Science \& Technology, vol. 25, no. 2, pp. 203-208, 1998.

[38] A. B. Siddique, M. F. Wright, and S. M. M. Ali, "Effects of time of sowing on the quality of pea seeds," Journal of Biological Sciences, vol. 2, no. 6, pp. 2380-2383, 2002.
[39] K. Fatonah, I. Suliansyah, and N. Rozen, "Electrical conductivity for seed vigor test in sorghum (Sorghum bicolor)," Cell Biology and Development, vol. 1, no. 1, pp. 6-12, 2017.

[40] M. Demir, "Conformity of vigor tests to determine the seed quality of safflower (Carthamus tinctorius L.) cultivars," Australian Journal of Crop Science, vol. 8, no. 3, pp. 455-459, 2014.

[41] L. Huang and Y. Yao, "Particulate structure of phytoglycogen nanoparticles probed using amyloglucosidase," Carbohydrate Polymers, vol. 83, no. 4, pp. 1665-1671, 2011.

[42] P. O. Powell, M. A. Sullivan, M. C. Sweedman, D. I. Stapleton, J. Hasjim, and R. G. Gilbert, "Extraction, isolation and characterisation of phytoglycogen from $s u-1$ maize leaves and grain," Carbohydrate Polymers, vol. 101, pp. 423-431, 2014.

[43] D. Ketthaisong, B. Suriharn, R. Tangwongchai, and K. Lertrat, "Changes in physicochemical properties of waxy corn starches at different stages of harvesting," Carbohydrate Polymers, vol. 98, no. 1, pp. 241-248, 2013.

[44] J. Verdier, D. Lalanne, S. Pelletier et al., "A regulatory network-based approach dissects late maturation processes related to the acquisition of desiccation tolerance and longevity of Medicago truncatula seeds," Plant Physiology, vol. 163, no. 2, pp. 757-774, 2013.

[45] J. R. Shaw and D. B. Dickinson, "Studies of sugars and sorbitol in developing corn kernels," Plant Physiology, vol. 75, no. 1, pp. 207-211, 1984.

[46] J.-G. Xu, Q.-P. Hu, X.-D. Wang, J.-Y. Luo, Y. Liu, and C.-R. Tian, "Changes in the main nutrients, phytochemicals, and antioxidant activity in yellow corn grain during maturation," Journal of Agricultural and Food Chemistry, vol. 58, no. 9, pp. 5751-5756, 2010.

[47] C. Y. Tsai, F. Salamini, and O. E. Nelson, "Enzymes of carbohydrate metabolism in the developing endosperm of maize,” Plant Physiology, vol. 46, no. 2, pp. 299-306, 1970.

[48] L. Li, M. Blanco, and J.-L. Jane, "Physicochemical properties of endosperm and pericarp starches during maize development," Carbohydrate Polymers, vol. 67, no. 4, pp. 630-639, 2007. 